\title{
A tectonic interpretation of NW-SE strike-slip faulting during the 2004 off the Kii peninsula earthquakes, Japan: Probable tear of the Philippine Sea plate
}

\author{
Takayuki Miyoshi ${ }^{1}$ and Katsuhiko Ishibashi ${ }^{2}$ \\ ${ }^{1}$ Graduate School of Science and Technology, Kobe University, Kobe 657-8501, Japan \\ ${ }^{2}$ Research Center for Urban Safety and Security, Kobe University, Kobe 657-8501, Japan
}

(Received May 9, 2005; Revised July 27, 2005; Accepted July 29, 2005)

\begin{abstract}
The 2004 off the Kii peninsula earthquakes $\left(M_{w} 7.5\right.$ for the main shock) occurred within the subducting Philippine Sea (PHS) plate near its boundary, the Nankai trough, southwest Japan. The rupture mode of the foreshock-main shock-aftershock sequence was complicated, a combination of ENE-WSW striking (almost trough parallel) reverse faulting beneath the trough and NW-SE trending (almost trough normal) strike-slip faulting mostly on the landward side of the former. In this paper, we discuss the tectonic meaning of this NW-SE running strike-slip fault. We examined hypocenter distribution and focal mechanisms of slab earthquakes from October 1997 through September 2004 and confirmed a NW-SE striking tear of the PHS slab beneath the middle part of the Kii Peninsula pointed out by Miyoshi and Ishibashi (2004). According to the Earthquake Research Committee (2004) there is a NW-SE trending structural discontinuity in the PHS crust to the southeast of the main shock epicenter. Putting all features together, we interpret that there is a NW-SE striking fracture within the PHS plate continuously from the Nankai trough region to the slab beneath the Kii Peninsula, and that a partial rupture of this fracture occurred during the off the Kii peninsula earthquakes together with trough-parallel reverse faulting. It should be noted that two disastrous $M$ 7-class slab earthquakes seem to have occurred along this tear beneath the peninsula in 1899 and 1952.
\end{abstract}

Key words: 2004 off the Kii peninsula earthquakes, intra-oceanic-plate earthquake, Philippine Sea plate, slab tear, hypocentral distribution, focal mechanism.

\section{Introduction}

On September 5, 2004, a large earthquake of $M_{J}$ (magnitude assigned by the Japan Meteorological Agency (JMA); e.g., Utsu, 2002) 7.4 took place just beneath the Nankai trough off the southeastern coast of the Kii Peninsula, southwest Japan (Fig. 1). The Nankai trough is the boundary between the Philippine Sea (PHS) and the Eurasian (EUR) (or Amurian/AMR) plates, where the former is being subducted beneath the latter northwestward and along which great interplate earthquakes have recurred with spatio-temporal regularity (e.g., Ando, 1975). In the near future, the next great interplate event called the Tonankai earthquake is anticipated to occur off the Kii Peninsula (e.g., Earthquake Research Committee, 2001).

The 2004 earthquake was a rupture within the PHS plate. Such a large intraplate event is so far unknown in this area. In addition, its rupture process was complicated; due to a $\mathrm{N}-\mathrm{S}$ compression, NW-SE trending right-lateral strike-slip faulting took place first and E-W striking reverse faulting followed on a larger scale (Yagi, 2004; Park and Mori, 2005). Seno (2005) interpreted this complex rupture mode as the result of the stress state in this region, which he inferred as being the superposition of the bending stress

Copyright (c) The Society of Geomagnetism and Earth, Planetary and Space Sciences (SGEPSS); The Seismological Society of Japan; The Volcanological Society of Japan; The Geodetic Society of Japan; The Japanese Society for Planetary Sciences; TERRAPUB. and the stress due to a collision to the east of this area. However, the structural meaning of the NW-SE running strike-slip fault itself has not yet been discussed, though it seems considerably large-scale and may be important for the subduction tectonics in this region.

On the other hand, we have been studying the geometry of the subducted PHS plate beneath southwest Japan based on the hypocentral distribution and focal mechanisms of slab earthquakes, and pointed out a NW-SE trending tear of the PHS slab beneath the middle part of the Kii Peninsula (Fig. 1; Miyoshi and Ishibashi, 2004). We inferred that the PHS slab is separated into two parts by this tear, with the southwestern part underlying the northeastern part. Though Miyoshi and Ishibashi (2004) only investigated the slab geometry deeper than $30 \mathrm{~km}$, mostly beneath the land area, the inferred slab tear seems to continue to the NW-SE striking rupture zone of the 2004 earthquake.

In this paper, we review the rupture mode of the 2004 off the Kii peninsula earthquakes including the main shock, the foreshock, and aftershocks, re-analyze the latest slab seismicity beneath the Kii Peninsula, and discuss the tectonic significance of the NW-SE trending rupture during this earthquake.

\section{The 2004 Off the Kii Peninsula Earthquakes}

On September 5, 2004, at 14:57 (UTC), an earthquake of $M_{J} 7.4\left(M_{w} 7.5\right)$ occurred at a depth of $44 \mathrm{~km}$ beneath the 


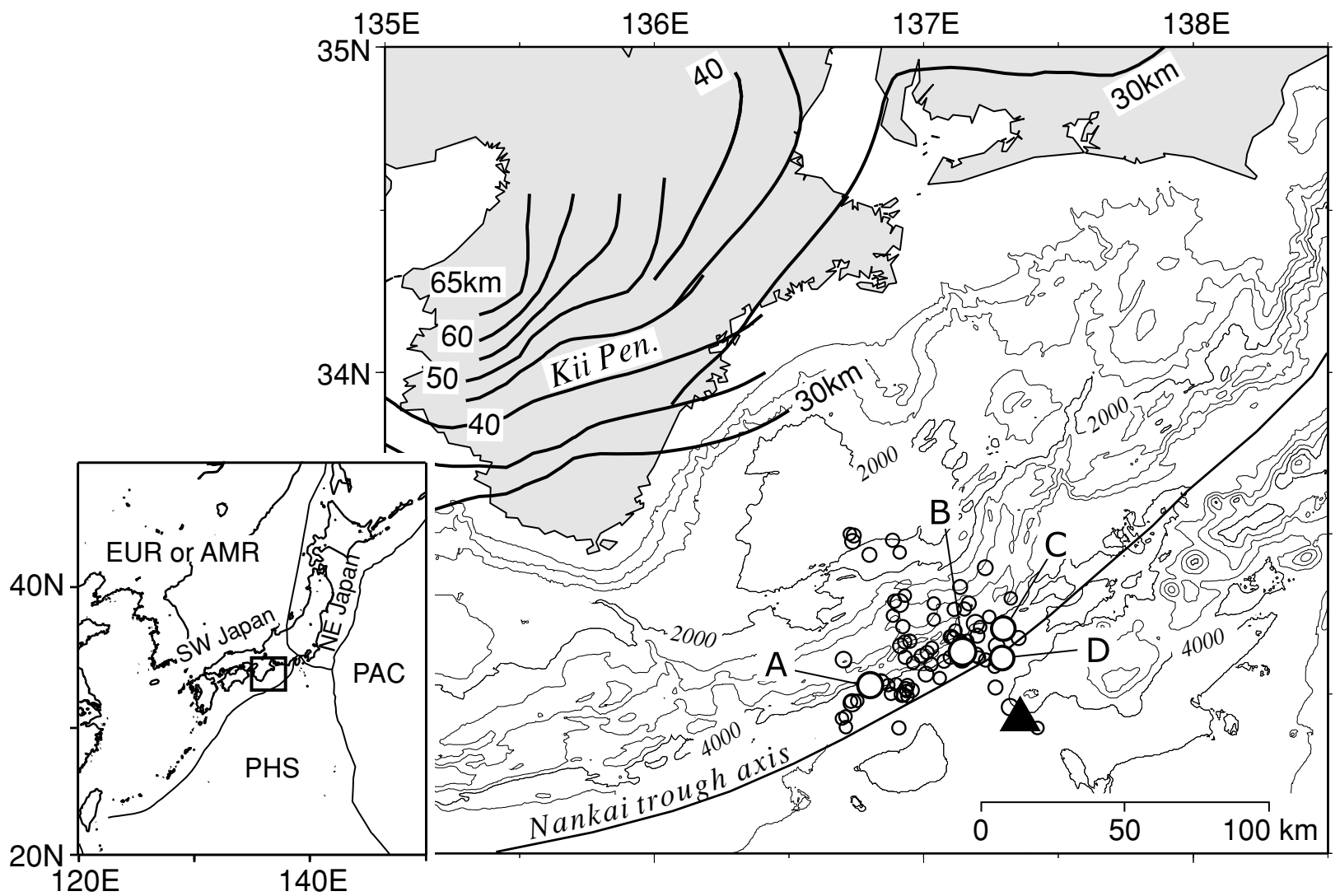

Fig. 1. Index map of the study area. Epicentral distribution of the 2004 off the Kii peninsula earthquakes is shown for events of $M_{J} \geq 4$ during September. Data are from the integrated hypocenter database prepared by JMA. A to D denote epicenters of the foreshock, main shock and two largest aftershocks, respectively (see text). Thick curves in the land area are depth contours of the upper surface of the Philippine Sea slab estimated by Miyoshi and Ishibashi (2004). The solid triangle to the southeast of B (main shock) represents the area where a NW-SE trending structural discontinuity with the southwestern side down was detected in the ocean bottom by a reflection survey (Earthquake Research Committee, 2004). Bathymetric data (in meters) are after the Japan Oceanographic Data Center (J-EGG500). AMR, Amurian plate; EUR, Eurasian plate; PAC, Pacific plate; PHS, Philippine Sea plate.

vicinity of the Nankai trough axis, off the southeast coast of the Kii Peninsula (B in Figs. 1 to 4 ). It was preceded by a $M_{J} 6.9\left(M_{w} 7.3\right)$ foreshock at 10:07 (UTC) on the same day (depth, $38 \mathrm{~km}$; A in Figs. 1 to 3), and followed by many aftershocks including the largest one of $M_{J} 6.5\left(M_{w} 6.3\right.$; depth, $36 \mathrm{~km}$; 14:58 UTC on the 8th; D in Figs. 1 to 4) and the second largest one of $M_{J} 6.4$ (depth, $41 \mathrm{~km} ; 23: 29$ UTC on the 6th; C in Figs. 1 to 3). (All these parameters are after the Earthquake Research Committee (2004).) The depth control by JMA in this offshore area is not good, and the actual depth of this activity may be a little shallower (Sakai et al., 2005; Ito et al., 2005). According to Sakai et al. (2005), who carried out urgent aftershock observation using ocean bottom seismometers, the depth range of aftershocks is about $5-25 \mathrm{~km}$.

Focal mechanisms of these four large events (Fig. 2) show E-W striking reverse faulting, not low-angle, due to $P$-axes in a N-S direction. Judging from these mechanisms, epicentral locations, focal depths, and the hypocentral distribution of the foreshock-main shock-aftershock sequence, this seismic activity is considered basically troughparallel reverse faulting within the PHS plate that is just starting subduction at the Nankai trough.

However, there is a very noticeable point in the aftershock distribution as follows. As can be seen in Figs. 1 to 3, there is a remarkable lineament of aftershocks in the NWSE direction, mainly on the landward side of the main shock epicenter. We compiled the distribution of focal mechanisms of the foreshocks and aftershocks based on the F-net data from NIED (National Research Institute for Earth Science and Disaster Prevention), as is shown in Fig. 2. Many aftershocks in this group have focal mechanisms of rightlateral strike-slip with one nodal-plane parallel to the direction of the lineament.

Yagi (2004) investigated the rupture process of this earthquake sequence by waveform inversion of teleseismic body waves recorded at IRIS-DMC stations. He obtained the result that the foreshock was northerly-dipping reverse faulting and the main shock, southerly dipping reverse one, conjugate to each other. He discovered, however, that during the main shock, a vertical right-lateral strike-slip fault along the NW-SE trending aftershock area had begun to rupture some $10 \mathrm{sec}$ prior to the main reverse faulting. Yagi's (2004) estimation of the length of the strike-slip fault is about $90 \mathrm{~km}$ with a maximum slip of around $3 \mathrm{~m}$, while the estimated length and maximum slip of the main thrust are $110 \mathrm{~km}$ and about $4 \mathrm{~m}$, respectively. Park and Mori (2005) also found out that during the main shock, a $M_{w}$ $6.1\left(M_{0}=2.0 \times 10^{18} \mathrm{~N} \cdot \mathrm{m}\right)$ strike-slip event had occurred first on a NW-SE striking plane followed by a $M_{w} 7.5$ 


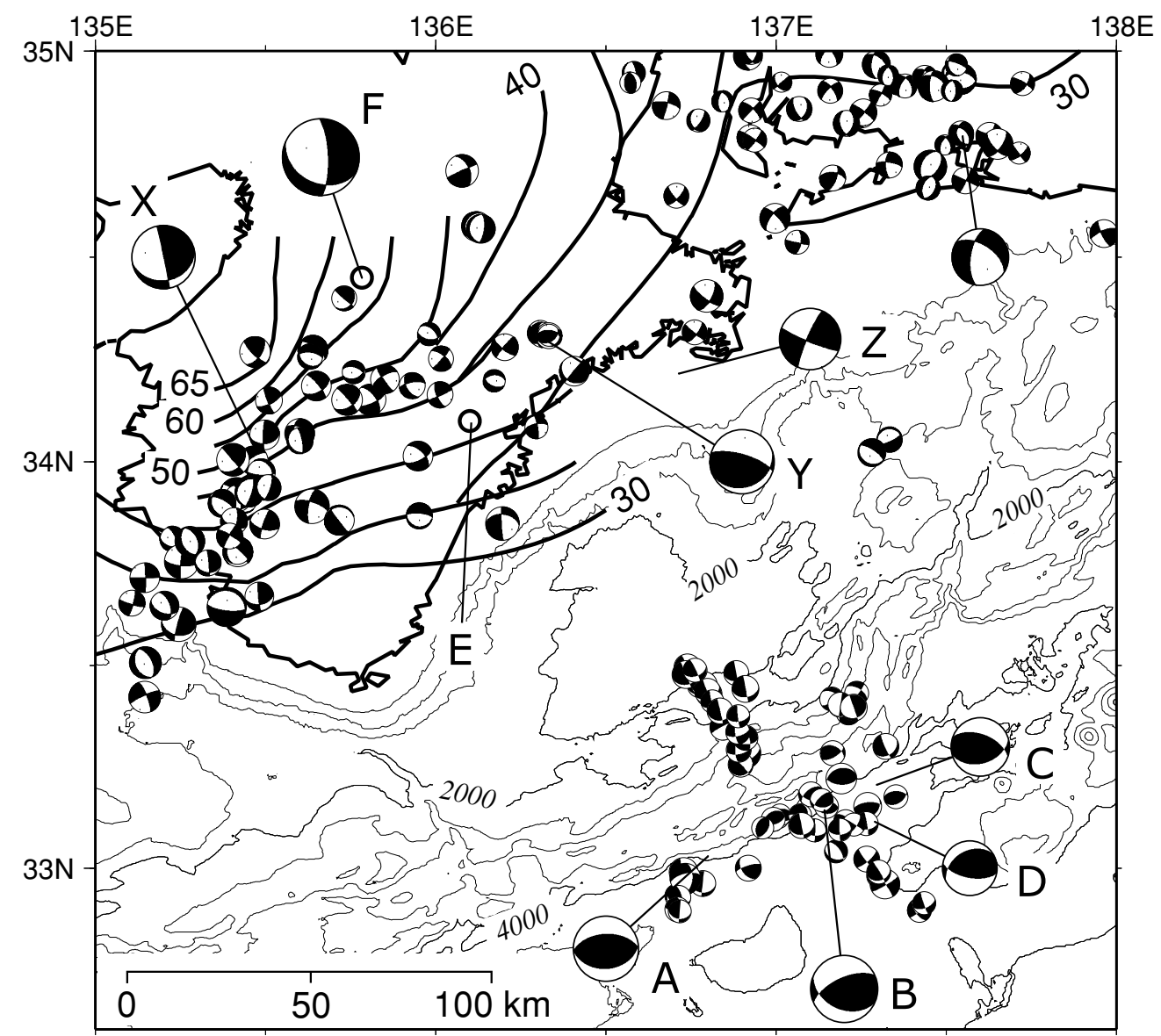

Fig. 2. Focal mechanisms (lower focal hemisphere) in and around the Kii Peninsula for the period from October 1997 through September 2004 after JMA (in and around the land area; depth, 30 to $100 \mathrm{~km}$ ) and after F-net of NIED (for the 2004 off the Kii peninsula earthquakes). Most of these earthquakes are considered to have occurred within the PHS plate. The sizes of beach balls vary with magnitudes (for JMA data) and seismic moments (for F-net data). Events A to D are the same as in Fig. 1. Event F is the 1952 Yoshino earthquake of $M_{J} 6.8$, whose focal mechanism is after Kikuchi et al. (2002). Events $\mathrm{X}$ to $\mathrm{Z}$ are earthquakes of $M_{J} \geq 5$ around the Kii Peninsula. Depth contours of the PHS slab upper surface and submarine isobaths are the same as in Fig. 1.

$\left(M_{0}=2.1 \times 10^{20} \mathrm{~N} \cdot \mathrm{m}\right)$ thrust event which had started 4.2 $\mathrm{km}$ southeast of the initial epicenter about $14 \mathrm{sec}$ later. Hara (2005) inferred from long-period body wave data that the main shock had been a compound event consisting of two different source mechanisms, a strike-slip component dominating during the first $20 \mathrm{sec}$ and a thrust mechanism predominant between 30 and $40 \mathrm{sec}$ after the rupture initiation.

Therefore, we consider that NW-SE striking faulting along the remarkable aftershock lineation is significant during this earthquake sequence, though the main rupture took place on an ENE-WSW striking reverse fault. Baba et al. (2005) and Satake et al. (2005), who analyzed tsunami waveform data, and Hashimoto et al. (2005), who analyzed GPS data, also concluded the necessity of the strike-slip fault for their source modeling.

\section{Slab Tear beneath the Middle Part of the Kii Peninsula}

Miyoshi and Ishibashi (2004) delineated the geometry of the upper surface of the seismic PHS slab beneath the middle part of southwest Japan including the Kii Peninsula based on hypocentral distribution of slab earthquakes, assuming that the upper boundary of slab earthquake distribution roughly coincides with the slab upper surface.
They used earthquakes during the period from October 1997 through December 2002 in the integrated hypocenter database prepared by JMA. Their estimation of depth contours of the slab upper surface in the region around the Kii Peninsula is shown in Fig. 1. They inferred that the slab beneath the middle part of the Kii Peninsula is torn into two parts along a narrow belt running roughly northwestward, with the southwestern part underlying the northeastern part.

In the present study, we re-examined this interpretation by adding hypocenter data until the end of September 2004. Figure 3 is the epicentral distribution of earthquakes with focal depths 30-100 km (landward side) and 0-100 km (seaward side) during the period from October 1997 through September 2004. Data are from the JMA's integrated hypocenter database. The depth error for most events beneath the land area is estimated at less than $3 \mathrm{~km}$. Figure 4 shows vertical cross sections of hypocenter distribution of earthquakes plotted in Fig. 3, in six belts of $10 \mathrm{~km}$ width along the lines a to $\mathbf{f}$ indicated in Fig. 3.

In the $\mathbf{d}$, $\mathbf{e}$ and $\mathbf{f}$ cross sections in Fig. 4 , it is clear that the upper boundary of the slab earthquake distribution is almost flat on the northeastern side, and dipping gently on the southwestern side, showing abrupt differences in depth around line b. This suggests that the dip directions 


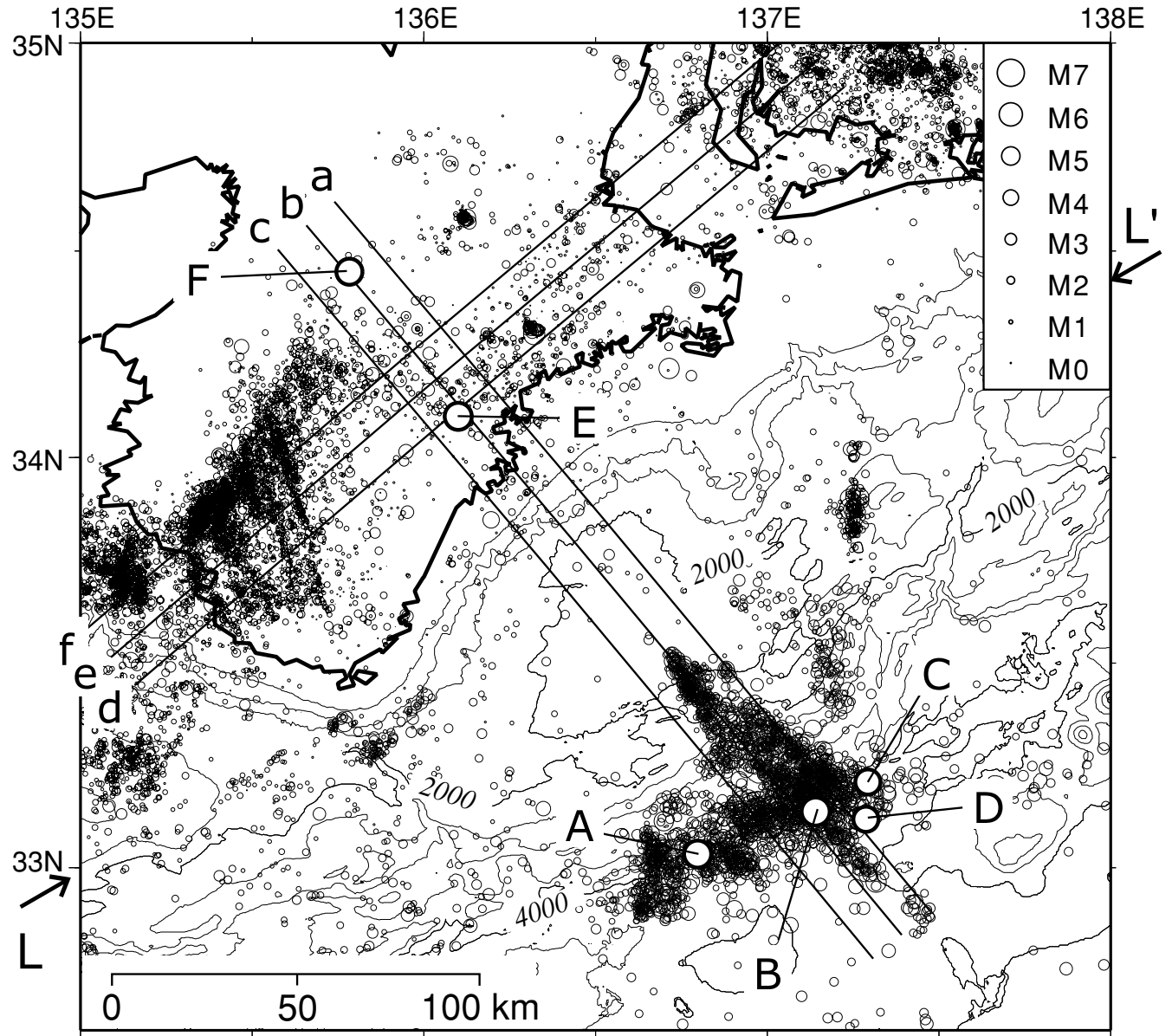

Fig. 3. Epicentral distribution of earthquakes $\left(M_{J} \geq 0\right.$; focal depth, 30 to $100 \mathrm{~km}$ on the landward side of $\mathrm{L}-\mathrm{L}^{\prime}$ and 0 to $100 \mathrm{~km}$ on the sea side) for the period from October 1997 through September 2004. Data are from the integrated hypocenter database prepared by JMA. Most of them are considered to have occurred within the PHS plate. Lines a to f correspond to the vertical cross sections shown in Fig. 4. A to D are the same as in Fig. 1. As for events E and F, see text. Submarine isobaths are the same as in Fig. 1.

of the slab on the northeastern and the southwestern sides are different from each other, and that the PHS slab is not continuous in the NE-SW direction but torn into two parts, or at least considerably distorted, along a narrow belt near the line b, as pointed out by Miyoshi and Ishibashi (2004). In Fig. 4, the slab upper surface estimated by them is shown by thin lines, which fit well the latest slab seismicity, too.

Focal mechanisms in and near the land area illustrated in Fig. 2 have been determined by JMA for earthquakes with focal depths $30-100 \mathrm{~km}$ during the period from October 1997 through September 2004. As Miyoshi and Ishibashi (2004) showed by the distribution of $P$ - and $T$-axes, beneath the northeastern part of the Kii Peninsula reverse or strike-slip types with $T$-axes nearly in an E-W direction are predominant, while beneath the southwestern part, normal or strike-slip types with $T$-axes in a NNE-SSW direction are predominant. Thus, the northeastern and the southwestern parts of the slab are considered to be in different stress regimes from each other, again suggesting that the slab is separated into two parts.

There remains the possibility of another interpretation that the PHS slab itself is continuous in this area with just the seismogenic layers being different in the northeastern and the southwestern parts. In this interpretation, the slab earthquakes on the northeastern side in boxes $\mathbf{d}, \mathbf{e}$ and $\mathbf{f}$ in
Fig. 4 are considered to be occurring in the oceanic crust and those on the southwestern side, in the oceanic mantle. The hypocenter distribution in the central part is regarded as a double seismic zone in the identical slab. However, because the reason why the seismogenic layer suddenly changes from the crust to mantle is unknown, we do not adopt this interpretation.

After all, we confirm Miyoshi and Ishibashi's (2004) inference that the PHS slab beneath the Kii Peninsula is separated into two parts or strongly distorted along a narrow tear belt beneath the middle part of the peninsula striking roughly northwestward. Although they emphasized overlapping of slabs that the southwestern part underlay the northeastern part, this point should be investigated more carefully in connection with the problem of an apparent double seismic zone.

\section{Discussion}

The seaward extension of the NW-SE trending tear of the PHS slab beneath the Kii Peninsula, which has been confirmed in the previous section, can be connected smoothly with the NW-SE striking fault plane of the 2004 off the Kii peninsula earthquakes. Yagi's (2004) interpretation for this faulting during the main shock is vertical right-lateral with a slip angle of $150^{\circ}$, the southwestern side going downward, 


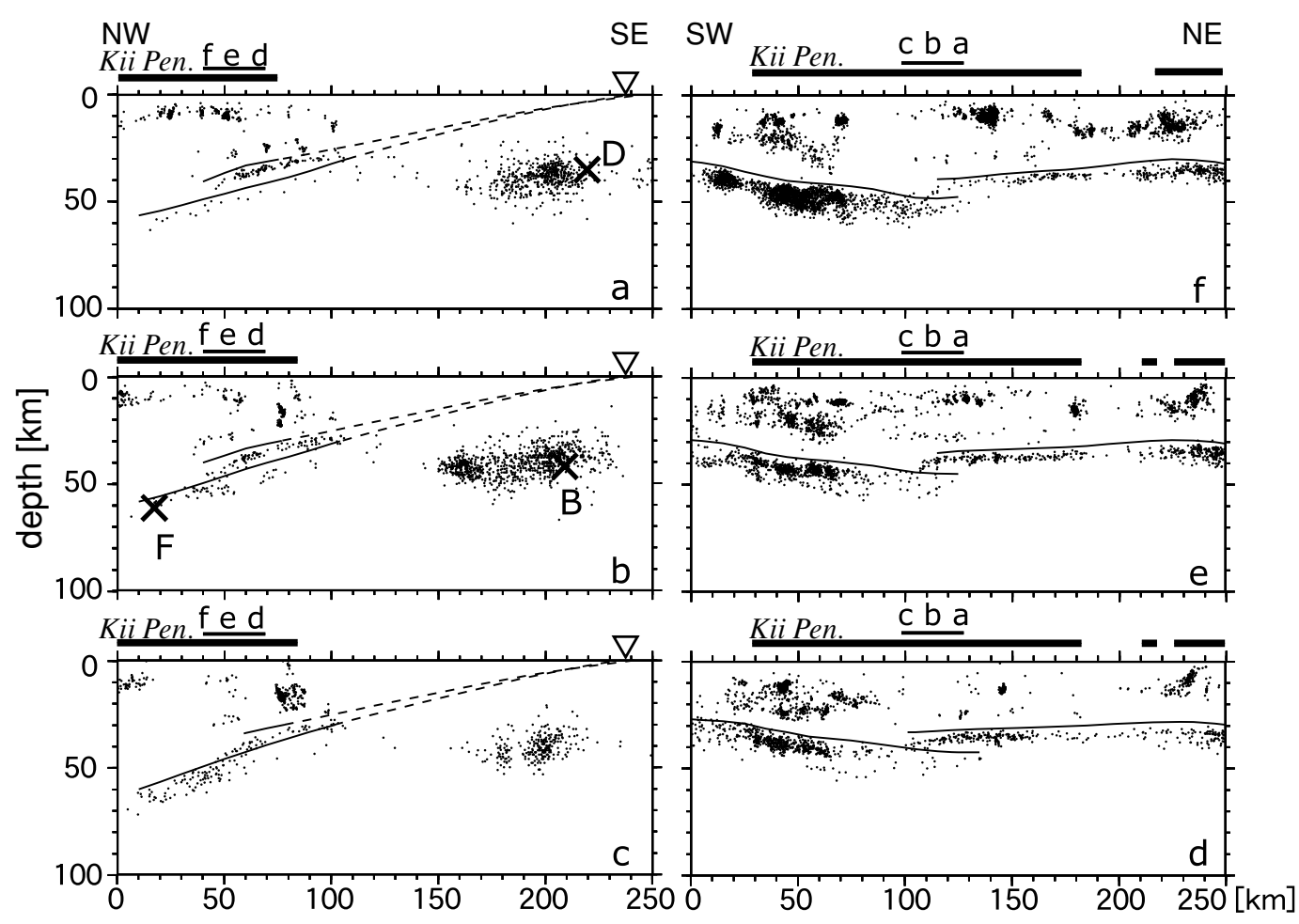

Fig. 4. Vertical cross sections of hypocenter distribution of earthquakes shown in Fig. 3 (events shallower than $30 \mathrm{~km}$ have been added on the landward side just for reference). In each box, earthquakes within $10 \mathrm{~km}$ width along the corresponding line in Fig. 3 are plotted. Thin solid lines in boxes indicate the upper surface of the PHS slab estimated by Miyoshi and Ishibashi (2004) (thin broken lines are just for reference). Thick and the thickest solid lines and inverted triangles on the frames represent positions of the crossing sections, land parts, and the trough axis, respectively. Events B, D and $\mathrm{F}$ are the same as in the previous figures.

and the mode is in agreement with the inferred slab tear beneath the Kii Peninsula.

According to the Earthquake Research Committee (2004), a NW-SE trending structural discontinuity in the oceanic crust, the southwestern side falling down, has been found near the aftershock area, to the southeast of the main shock epicenter and the Nankai trough axis (solid triangle in Fig. 1). This structure also matches the feature of the slab tear beneath the Kii Peninsula. It should be noted that the NW-SE trending aftershock area extends to the southeast side of the trough axis (Figs. 1 to 3 ) and that the strikeslip fault in Yagi's (2004) model also stretches southeastward beyond the main shock epicenter and the trough axis. Therefore, a fracture, as an origin of the slab tear, may preexist on the ocean side of the Nankai trough. The submarine topography, however, shows no feature of a fracture. Further investigation is necessary to clarify the true nature.

Two large disastrous non-shallow earthquakes beneath the Kii Peninsula have occurred along the inferred slab tear. One is the 1899 Southeastern-Kii-Peninsula earthquake that caused widespread damage in the peninsula. The epicenter, $M_{J}$, and focal depth are estimated at E in Figs. 2 and 3, as 7.0 , and 40 to $50 \mathrm{~km}$, respectively (Utsu, 1979). Since its aftershock activity was low, it is considered to be a slab earthquake. But its focal mechanism is unknown. The other is the 1952 Yoshino earthquake $\left(M_{J}, 6.8\right.$; depth, $60 \mathrm{~km}$; F in Figs. 2 to 4), which also caused considerable damage in and around the Kii Peninsula. Miyoshi and Ishibashi (2004) considered this event to have occurred within the slab on the southwestern side of the tear because its focal mechanism

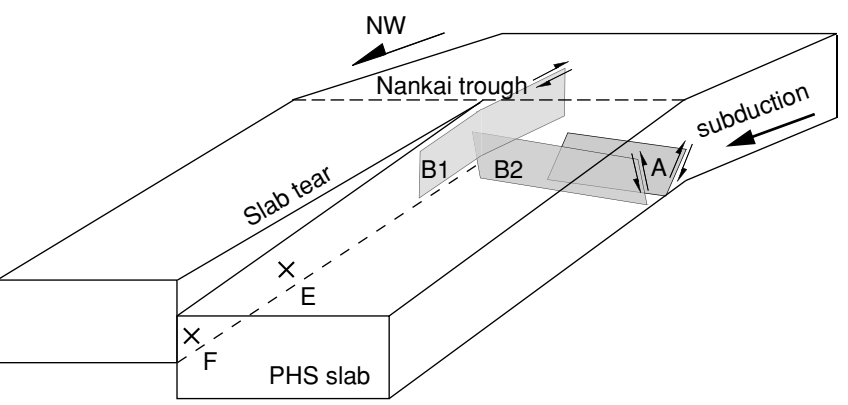

Fig. 5. Schematic illustration of the faults of the 2004 off the Kii peninsula earthquakes and the inferred slab tear of the PHS plate. A, B1 and B2 correspond to the foreshock, the NW-SE trending strike-slip fault of the main shock and the ENE-WSE running reverse fault of the main shock, respectively. Yagi (2004) and Park and Mori (2005) have been referred to for illustration. Crosses E and F indicate the 1899 Southeastern-Kii-Peninsula earthquake and the 1952 Yoshino earthquake, respectively.

by Kikuchi et al. (2002) (F in Fig. 2) was similar to X in the southwestern slab (Fig. 2). There remains the possibility, however, that it took place just along the slab tear, though $\mathrm{F}$ in Fig. 2 does not match the tearing.

Faulting of the 2004 off the Kii peninsula earthquakes and the inferred slab tear of the PHS plate are illustrated schematically in Fig. 5. The role of strike-slip faulting along the slab tear during this earthquake is considered as follows. Due to critically increased trough-normal compressional stress in the deeper part of the PHS plate around the Nankai trough, which is associated with bending, reverse 
faulting of the foreshock (A in Fig. 5) occurred first. It accelerated the subduction of the PHS plate on the southwestern side of the tear and added right-lateral shear stress along the tear. Then, strike-slip faulting (B1 in Fig. 5) on the tear took place as the first stage of the main shock, which accelerated the descending motion of the PHS plate on the southwestern side of the tear and triggered large-scale reverse faulting of the second stage of the main shock (B2 in Fig. 5). This is, though very qualitative, an alternative explanation for the triggering of subsequent ruptures to the explanation by simple calculations of static stress change, which Park and Mori (2005) tried but could not get a good result.

The inferred slab tear is apparently situated in the middle part of the source regions of the 1944 and the hypothetical future Tonankai earthquakes (e.g., Earthquake Research Committee, 2001). The relationship between the inferred slab tear and rupture process of the Tonankai earthquake is a very interesting and important problem for the future investigation.

\section{Conclusion}

We present a tectonic interpretation of NW-SE trending strike-slip faulting during the 2004 off the Kii peninsula earthquakes, which has not yet been discussed. By reviewing the rupture mode of the 2004 earthquakes and re-examining Miyoshi and Ishibashi's (2004) inference of a PHS slab tear beneath the Kii Peninsula, we propose a hypothesis that there exists a NW-SE striking tear or a strongly distorted narrow belt of the PHS plate continuously from the ocean side of the Nankai trough to the deeper part beneath the Kii Peninsula. We interpret that NW-SE trending strikeslip faulting in the 2004 earthquakes was a partial rupture of this tear and played an important role during the earthquake sequence. Along the slab tear beneath the Kii Peninsula, two $M$ 7-class disastrous earthquakes seem to have occurred in 1899 and 1952. Further investigation is necessary to clarify the true nature and the tectonic significance of this tear of the PHS plate.

Acknowledgments. In this study, we used the hypocenter database processed by the Japan Meteorological Agency (JMA) and the Ministry of Education, Culture, Sports, Science and Technology (MEXT) of the Japanese Government using waveform data from various universities and research institutes. We also used Fnet focal mechanism data from the National Research Institute for Earth Science and Disaster Prevention (NIED). We are grateful to them for providing valuable data. We thank two reviewers, Dr. Yoshihiro Ito and Dr. Terry Webb, and the editor, Prof. Kiyoshi Yomogida, for their helpful comments. GMT (Wessel and Smith, 1995) was used for drawing figures. This study was done as a part of the project " 21 century COE Program-Origin and Evolution of Planetary System" of the Graduate School of Science and Technology, Kobe University, which is promoted by the MEXT.

\section{References}

Ando, M., Source mechanisms and tectonic significance of historical earthquakes along the Nankai trough, Japan, Tectonophysics, 27, 119-140,
1975

Baba, T., P. R. Cummins, and T. Hori, Compound fault rupture during the 2004 off the Kii Peninsula earthquake (M7.4) inferred from highly resolved coseismic sea-surface deformation, Earth Planets Space, 57, 167-172, 2005.

Earthquake Research Committee, Headquarters for Earthquake Research Promotion, On the long-term evaluation of earthquakes along the Nankai trough (September 27, 2001), http://www.jishin.go.jp/main/ index.html, 2001 (in Japanese).

Earthquake Research Committee, Headquarters for Earthquake Research Promotion, Seismic activity off-shore southeast of the Kii Peninsula (October 13, 2004), http://www.jishin.go.jp/main/index-e.html, 2004.

Hara, T., Change of the source mechanism of the main shock of the 2004 off the Kii peninsula earthquakes inferred from long period body wave data, Earth Planets Space, 57, 179-183, 2005.

Hashimoto, M., K. Onoue, F. Ohya, Y. Hoso, K. Segawa, K. Sato, and Y. Fujita, Crustal deformations in Kii peninsula associated with the SE off the Kii peninsula earthquake sequence of September 5, 2004 derived from dense GPS observations, Earth Planets Space, 57, 185-190, 2005.

Ito, Y., T. Matsumoto, H. Kimura, H. Matsubayashi, K. Obara, and S. Sekiguchi, Spatial distribution of centroid moment tensor solutions for the 2004 off Kii peninsula earthquakes, Earth Planets Space, 57, 351356, 2005.

Kikuchi, M., M. Nakamura, and K. Yoshikawa, Source process of the Yoshino earthquake of July 18, 1952, inferred from low-gain seismograms, Abstracts of the 2002 Japan Earth and Planetary Science Joint Meeting (CD-ROM), S051-001, 2002 (in Japanese with English abstract).

Miyoshi, T. and K. Ishibashi, Geometry of the seismic Philippine Sea slab beneath the region from Ise Bay to western Shikoku, southwest Japan, Zisin (J. Seism. Soc. Jpn.), Second Ser., 57, 139-152, 2004 (in Japanese with English abstract).

Park, S. C. and J. Mori, The 2004 sequence of triggered earthquakes off the Kii peninsula, Japan, Earth Planets Space, 57, 315-320, 2005.

Sakai, S., T. Yamada, M. Shinohara, H. Hagiwara, T. Kanazawa, K. Obana, S. Kodaira, and Y. Kaneda, Urgent aftershock observation of the 2004 off the Kii Peninsula earthquake using ocean bottom seismometers, Earth Planets Space, 57, 363-368, 2005.

Satake, K., T. Baba, K. Hirata, S. Iwasaki, T. Kato, S. Koshimura, J. Takenaka, and Y. Terada, Tsunami source of the 2004 off the Kii Peninsula earthquakes inferred from offshore tsunami and coastal tide gauges, Earth Planets Space, 57, 173-178, 2005.

Seno, T., The September 5, 2004 off the Kii Peninsula earthquakes as a composition of bending and collision, Earth Planets Space, 57, 327 $332,2005$.

Utsu, T., Seismicity of Japan from 1885 through 1925-A new catalog of earthquakes of $M \geq 6$ felt in Japan and smaller earthquakes which caused damage in Japan, Bull. Earthq. Res. Inst., Univ. Tokyo, 54, 253308, 1979 (in Japanese with English abstract).

Utsu, T., Relationships between magnitude scales, in International Handbook of Earthquake and Engineering Seismology, Part A, IASPEI, edited by W. H. K. Lee, H. Kanamori, P. C. Jennings, and C. Kisslinger, pp. 733-746, Academic Press, New York, 2002 (Full manuscript is given in Utsu3FullManuscript.pdf on the attached Handbook CD \#1, directory/44Utsu3).

Wessel, P. and W. H. F. Smith, New version of the Generic Mapping Tools released, EOS Trans. Am. Geophys. Union, 76, 329, 1995.

Yagi, Y., On the earthquakes which occurred southeast-off the Kii Peninsula on September 5, 2004, http://iisee.kenken.go.jp/staff/yagi/eq/ Japan20040905/Japan20040905_1-j.html, 2004 (in Japanese).

T. Miyoshi (e-mail: tmiyoshi@kobe-u.ac.jp) and K. Ishibashi 